\title{
Modelling the Antecedent and Consequence of Consumer Perceived Deception in Loan Services
}

\author{
Mbawuni Joseph $^{1} \&$ Simon Gyasi Nimako ${ }^{2}$ \\ ${ }^{1}$ Faculty of Business Education, University of Education, Winneba, Ghana \\ ${ }^{2}$ Department of Management Studies Education, University of Education, Winneba, Kumasi Campus, Ghana \& Accra \\ Institute of Technology, Accra, Ghana \\ Correspondence: Mbawuni Joseph (PhD), Faculty of Business Education, University of Education, Winneba, Ghana. \\ Tel: 233-24-391-1000. E-mail: mbawuni@gmail.com
}

Received: October 4, 2014

Accepted: October 22, $2014 \quad$ Online Published: November 15, 2014

doi:10.5430/ijfr.v6n1p43

URL: http://dx.doi.org/10.5430/ijfr.v6n1p43

\begin{abstract}
This paper assesses the antecedent and consequence of consumer perceived deception (CPD) on consumer trust, satisfaction, attitude recommendation and intentions to acquire future loans from financial service providers. The proposed research model was tested using data from a survey of 371 loan customers of leading financial service providers in Ghana. Data were analysed using SmartPLS 2.0 for Partial Least Squares Structural Equation Modelling. The results show high information quality could significantly reduce CPD. Moreover, results indicate that CPD has negative effects on trust, satisfaction and likelihood to recommend loan service providers. However, CPD did not influence respondents' general attitude towards loans and future intentions for loan acquisition. This paper uniquely contributes to theory by testing a framework of antecedent and consequence of CPD in order to extend scholar's understanding of CPD in loan financial service context. The findings provide important implications for managing CPD in loan service delivery, and sustaining customer future intentions in spite of CPD in loan service. While this study is limited in terms of generalizability of the findings in developing countries, it provides avenues for further research to test the applicability of the proposed research model in financial markets in other research settings.
\end{abstract}

Keywords: perceived deception, trust, loan service, information quality, satisfaction, client recommendation

\section{Introduction}

Consumers are considered key to survival, profitability and long-term growth of business organisations (Kotler \& Keller, 2012; Reichheld, 1996; Zeithaml, 2000). Sam Walton, the founder of famous Wall Mart, said, "there is only one boss: the customer... He can fire everyone in the company, from the chairman down, simply by spending his money elsewhere." Therefore, organizations make considerable attempts to understand consumer behaviour in order to develop effective strategies to influence it to achieve organizational goals. One area of consumer behaviour which has received relatively little attention by scholars and practitioners is consumer perceived deception (CPD) and how it affects consumer behaviour in the context of financial service delivery.

In the provision of financial services such as loans, sale of shares, debentures, and other banking products, consumer misrepresentation and misleading can easily occur. This is because consumers require adequate amount of detailed and delicate information in order to make effective decisions in the area of acquiring and managing these financial facilities, which in some cases turn out to be different from consumer expectations.

Deception is considered as one of the major ethical issues in advertising and delivery of service products (Hyman, Tansey \& Clarc, 1994) and can be deadly to financial service providers. Much of the past studies on consumer deception has been done on deception in different disciplines such as psychology (Ekman, 1992), psychiatry (Ford, 1996), human communication (McCornack, 1992), Internet (Grazioli \& Jarvenpaa, 2003; Román, 2007), and advertising (Chaouachi, Rached, \& Saied, 2012; Newell, Goldsmith, \& Banzhaf, 1998). Yet there is limited empirical evidence of the influence on consumer behaviour, especially in the context of financial service delivery.

Moreover, existing studies have established that deception can influence sales volume, evaluation of product attributes (Estrada, 2006; Newell, Goldsmith, \& Banzhaf, 1998) and other consumer behaviour such as attitude towards advertising (Chaouachi, et al., 2012) and consumer loyalty to service providers (Limbu, Wolf, \& Lunsford, 
2011; Román, 2010). There is void in the extant literature regarding evidence of the antecedents and effects of CPD on consumer behaviour such as trust, satisfaction and behavioural intentions for service providers, especially in financial service context. Given that CPD can be detrimental to firms and negatively affect consumer behavour (Chaouachi et al., 2012; Limbu et al., 2011; Román, 2010), it becomes critically important to understand the extent to which CPD can affect consumer behaviour in financial service delivery. Therefore, in this study, the main purpose is to extend research on consumer deception to the financial services (loans) contexts and assess the antecedent and consequence of CPD in areas such as consumer trust, satisfaction, attitude, recommendation of financial service providers and intentions to acquire future loans.

The rest of the paper is organised as follows. It continues with relevant literature review and development of conceptual framework and hypothesis. This is followed by a description of the research methodology and data analysis. It then presents results, discussion of findings, and theoretical and practical implications of the research. It finally ends with discussion of limitations, areas of further research and conclusion.

\section{Literature Review}

\subsection{Concept of Consumer Perceived Deception (CPD)}

In the United States, the Federal Trade Commission (FTC) defines deception as any "representation, omission or practice that is likely to mislead the consumer acting reasonably in the circumstances, to the consumer's detriment" (FTC, 1983). This implies that the consumer must proof that the claim of deception is important to the consumer's purchase decision to be considered in order to be considered as deceptive. Buller and Burgoon (1996) believe that deception is "a deliberate message conveyed by a sender to create a false belief or conclusion at the receiver". This definition emphasizes the fact that deception is a deliberate attempt on the part of one party in the given contractual relationship. Thus, implied deception which cannot be proven to be intentional may not constitute deception in some cases.

In the area of interpersonal communication, Masip, Garrido and Herrero (2004, p.148) describe interpersonal deception as "the deliberate attempt, whether successful or not, to conceal, fabricate, and/or manipulate in any other way factual and/or emotional information, by verbal and/or nonverbal means, in order to create or maintain in another or in others a belief that the communicator considers false". Moreover, from a social perspective, Aditya (2001) defined deception in marketing as "any act, claim or message that (a) causes at least some consumers acting reasonably to make decisions that they would not otherwise make, (b) leads at least some consumers acting reasonably to believe something about the product, brand or manufacturer that is not verifiably true or (c) has the potential to foster distrust of any kind, general or specific, or in other ways causes an erosion of ethical values deemed desirable in society". In the domain of ecommerce, Román (2007) defined perceived deception as the extent to which the consumer believes that the online retailer uses deceptive or manipulative practices with the intent to persuade consumers to purchase the website's offerings. Similarly, Xiao and Tan (2006) believe that perceived deception refers to "the consumer's belief, held without sufficient evidence to warrant certainty, that the product recommendation agent is being deceptive".

In the contexts of financial service delivery, consumers can feel deceived when they realize that the financial service provider is not truthful to their terms and conditions of the financial product offered and/or is engaged in deceptive behaviour or practices related to the financial product offered to customers. For the purpose of this study, CPD in loan service is defined as the extent to which the customer believes that the financial service provider makes deliberate effort to hide vital information or use deceptive practices with the intent to persuade customers to acquire and service the loan products during a given time period. Therefore, CPD in loans service includes such things as financial service provider's attempt to conceal vital information about the loan policy, deducting charges on the loan without the knowledge of customer and hiding vital information from the customer.

\subsection{Dimensions of Consumer Perceived Deception (CPD)}

Chaouachi et al. (2012) developed a two-dimension model of CPD (See Figure 1). Their model offered the first multi-dimensional measurement scale of perceived deception in advertising. According to the authors, the first dimension "perceived veracity" is related to the degree of truthfulness estimated by the person exposed to the ad. The second dimension "ethic" reflects the extent to which deception in advertising is seen as an unethical practice that may harm consumers and competitors.

Chaouachi et al. (2012) justified the predictive validity of their CPD model by linking it to attitude towards a specific advertisement, suggesting that when consumers feel deceived by the information in a particular advertisement, it is likely to negatively affect the consumer's attitude towards the advertisement in question. Due to its conceptual 
soundness and empirical validity, we adopt the two-dimension model of CPD to provide a conceptual basis for understanding CPD in the present study.

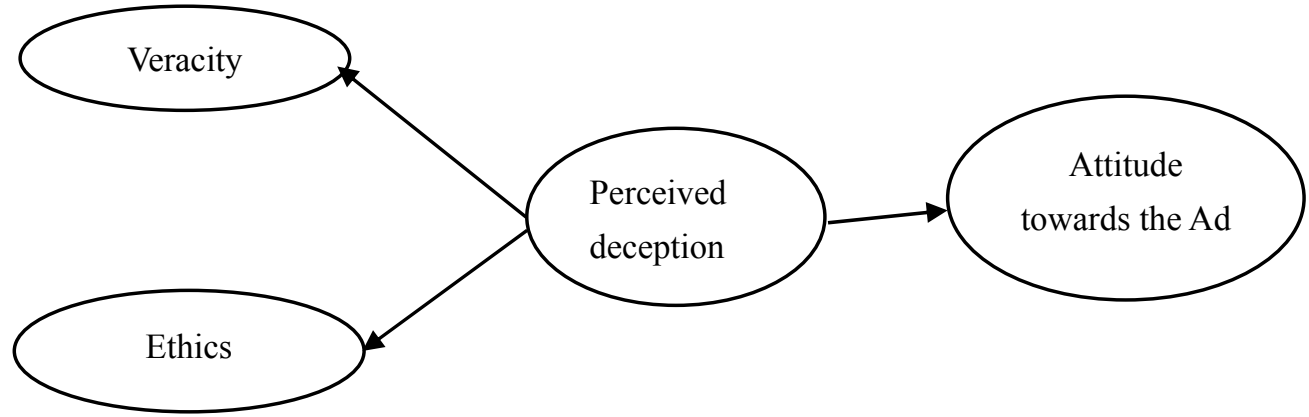

Figure 1. A two-dimension model of consumer deception (Chaouachi et al., 2012)

\subsection{Antecedents of $C P D$}

In the extant literature, there appears to be no empirical testing of the antecedents of CPD. However, there is some evidence that consumer deception fundamentally thrives on quality of information communicated to consumers. Drawing from past definitions of consumer deception (FTC, 1983; Buller \& Burgoon, 1996; Masip et al., 2004; Aditya, 2001; Román, 2007), it is implied that hiding or failing to communicate vital information about loan policy to customers can result in consumer deception. In addition, consumer misunderstanding of or ignorance of available and truthful information on loan service could also cause CPD. Thus, it appears that the quality of information provided by staff of financial firms to educate consumers regarding loan acquisition and payment processes could be an important antecedent to CPD. If information on loans policy is well communicated to customer, it can help reduce CPD in financial services.

\subsection{Effects of CPD on Consumer Behaviour}

Deception is considered as one of the major ethical issues to be raised in advertising (Hyman, Tansey, \& Clarc, 1994). Indeed, deception could influence consumers' beliefs in a dishonest way and can have negative consequences on their financial resource and their health (Boush, Friestad \& Wright, 2009). Deception also affects competition by the influence of consumer choice (Lord \& Kim, 1995) and results in an increase in market transaction costs (Gao, 2008). Romani (2006) found that the presence of deception can adversely affect levels of trustworthiness towards the source of information and willingness to buy. Existing literature has also demonstrated that consumer deception can affect attitude of consumers (Chaouachi et al., 2012; Newell et al., 1996). Chaouachi et al. (2012) found that when consumers feel deceived by the information in a particular advertisement, it is likely to have negative effect on the consumer's attitude towards the advertisement in question. However, in their study, Chaouachi et al. (2012) focused on attitude towards a specific advert and not general attitude toward adverts.

Two main gaps exist in the literature regarding the effects of the loans on consumer behaivour. First, in the existing literature, while CPD may negatively influence consumer attitude towards a particular service provider or a specific loan facility, it may not necessarily influence consumer attitude towards loans in general. This gap is important to explore since it would provide empirical evidence to support the claims that consumers' attitude may not always be negative towards all loan products per se, given that the consumer perceives the usefulness of the product or service in question to be high. This will in turn have important implications for financial service providers' loan marketing strategy. Therefore, in this study we explore consumer general attitude towards loans, and not attitude for specific a loan facility or a specific financial service provider's loans.

Second, past research has not fully explored the structural relationship between CPD and other consumer behaviours such as trust, satisfaction and behavioural intentions towards financial service providers in relationship management in financial markets. We researched into these gaps to provide theoretical and managerial implications for understanding the links between consumer perceived deception and relationship management in financial service delivery.

\subsection{Conceptual Framework and Hypothesis}

We developed a research model (Figure 1) to explore the research gaps identified and to test the links among antecedent and consequence of CPD. In the framework, CPD is conceptualised as a second-order, multi-dimensional constructs reflected in two key dimensions, namely, perceived veracity and ethics. It also depicts the one main antecedent of CPD, which is quality of loan policy information to customers as shown in Hypothesis H1. The framework shows loan policy information quality as one key antecedent of CPD, and five effects of CPD, which are trust, satisfaction, attitude towards loan acquisition, future intentions to acquire loans from a loan service provider 
and likelihood to recommend a loan facility of a loan service provider to others as in Hypothesis $\mathrm{H} 2$ to $\mathrm{H} 6$.

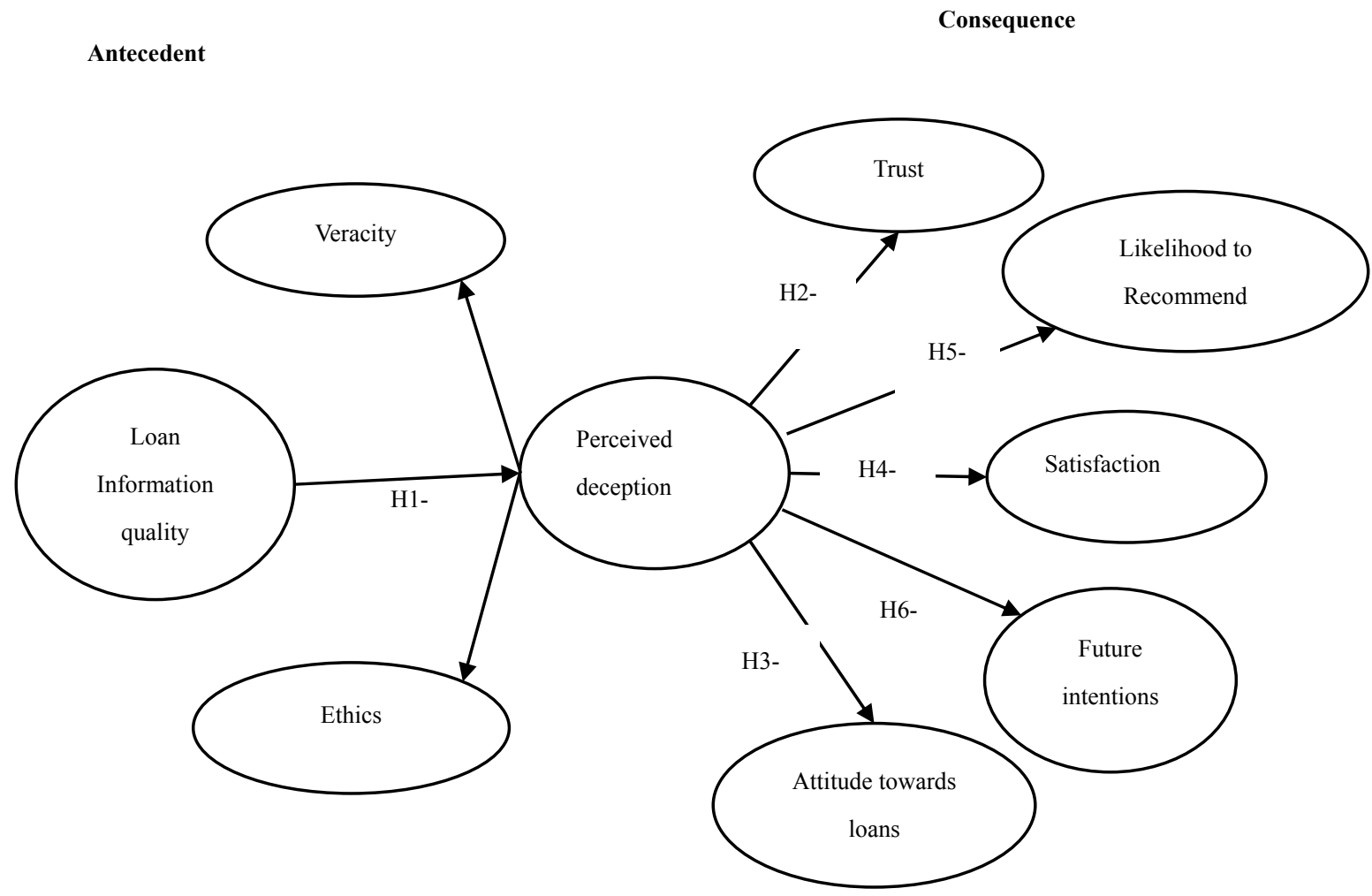

Figure 2. Conceptual framework and hypotheses

\subsubsection{Quality of Loan Information and CPD}

Loan information quality represents the ability of the financial service firm to explain to clients well all necessary loan terms and conditions. Generally, information quality is recognized as a vital aspect of financial service delivery (De Mel, McKenzie, \& Woodruff, 2011; Lymperopoulos, Chaniotakis, \& Soureli, 2006; Owusu-Frimpong, 2008; Xia, 2014). It is the responsibility of loan service providers to disclose all relevant and material information about loans to clients. Non-disclosure of and ineffective communication of loan policy to customers can cause CPD (Masip, Garrido, \& Herrero, 2004; Aditya, 2001; Román, 2007). When financial firms are able to communicate and educate consumers regarding loan acquisition and payment processes, it can reduce CPD. Failure to deliver quality information about loans to customer could result in high CPD. Thus, quality of information on loan policy could be a vital antecedent to CPD. Therefore, we hypothesize that:

H1: loan provider's delivery of quality of information on loan policy to customers will have significantly negative effect on consumer perceived deception. Specifically, the higher the quality of loan policy information delivered, the lower will be consumer perceived deception.

\subsubsection{Perceived Deception and Trust}

Trust is the "confidence in an exchange partner's reliability and integrity" (Morgan \& Hunt 1994, p. 23). Trust represents customers' confidence that a financial service provider will be truthful, trustworthy, and honest. Trust perception include the fact the financial service provider would not take advantage of the vulnerability of the consumer regarding the terms and conditions of the loan. When a consumer realizes that he/she has been deceived by a loan service provider, it is likely to reduce the customer's confidence and trust perception for the loan service provider (Román, 2010; Romani, 2006). This, therefore, leads to the hypothesis that:

$\mathrm{H} 2$ : Consumer perceived deception will have significantly negative effect on consumer trust for loan service provider.

\subsubsection{Perceived Deception and General Attitude towards Loans}

As already mentioned in the literature review, existing literature has established that consumer perceived deception has a significantly negative effect on attitude towards specific advertisement (Chaouachi et al., 2012; Newell et al., 1996). Attitude has also been found as a key factor in inducing many behavioural outcomes (Ajzen, 1991; Ajzen \& 
Fishbein, 2005; Nimako, Ntim, \& Mensah, 2014), making attitude an important aspect of consumer behaviour. In particular, Chaouachi et al. (2012) found that, when consumers perceive deception in advertisement, they tend to have negative attitude towards the advertisement in question. However, in their study, Chaouachi et al. (2012) focused on attitude towards a specific advert and not general attitude toward adverts. We suggest that in the area of loan service acquisition and payment, customer perception of manipulative practices by loan providers might have negative effect on consumer attitude towards particular loan offering from specific service providers, but might not have negative influence on customer's attitude towards loan service offerings in general. This implies that deceived consumers might still have positive attitude towards loan acquisition, probably due to high perceived usefulness of loan offerings in meeting the personal and business needs of the customer. This, therefore, leads to the hypothesis that:

H3: Consumer perceived deception will not have significantly negative effect on consumer's general attitude towards loans service.

\subsubsection{Perceived Deception and Satisfaction}

Satisfaction has been defined as "a person's feeling of pleasure or disappointment resulting from comparing a product's performance (outcome) in relation to his or her expectation." (Kotler \& Keller, 2006, p. 144). Consumers expect loans acquired to enable them achieve various personal and business needs. Customer can be disappointment and dissatisfied with the loan service delivery when they discover that the loans service provider has misled or taken undue advantage or misinform them in the loan acquisition and payment process. Consistent with existing CPD literature (Chaouachi et al., 2012; Román, 2010) and client satisfaction research (Cronin \& Taylor, 1992; Nimako, 2012) CPD in loan service delivery is likely to affect customer satisfaction for a specific loans process and offerings received or experienced. This leads to the following hypothesis:

H4: Consumer perceived deception will have significantly negative effect on consumer satisfaction for loans service.

\subsubsection{Perceived Deception and Likelihood to Recommend}

From the consumer behaivour literature, it has been established that consumers or clients exhibit many positive and negative word of mouth communication (WOMC) in many service contexts (Coulter \& Roggeveen, 2012; Lang, 2011; Lim \& Chung, 2011; Sweeney, Soutar, \& Mazzarol, 2012). Service recommendation by consumers has been one of the strongest marketing strategies in financial services. Clients are likely to either speak bad or good, and discourage or endorse a financial service provider depending on whether they are displeased or pleased with the financial service experienced (Coulter \& Roggeveen, 2012; Lim \& Chung, 2011; Nimako \& Mensah, 2013). Loan service provider's manipulative practices regarding loan acquisition and repayment process can have negative effect on the type of WOMC loan clients are likely to engage in about the loan provider (Coulter \& Roggeveen, 2012; Lim \& Chung, 2011; Sweeney, et al., 2012). Loan clients are likely to discourage family, friends and social referent groups from acquiring loans from a financial service provider if they perceive some deceptive practices on the part of service provider. This leads to the hypothesis that:

H5: Consumer perceived deception will have significantly negative effect on client's likelihood to recommend the loans service to others.

\subsubsection{Perceived Deception and Future Intention for Loan}

Clients' re-patronage intentions have been found to be strongly linked to previous consumer engagement, happiness and satisfaction experiences with service providers (Belanche, Casaló, \& Guinalíu, 2013; Bolton, 2011; Kotler, \& Keller, 2012; Reichheld, 1996). Clients' future intention for continued relationship with a loan service provider expresses the value of a relationship. Businesses thrive on repeated business and loyalty of customers (Kotler, \& Keller, 2012; Reichheld, 1996). Therefore, whatever affects the future repeated business between firm-customer relationship constitute an important issue for managerial strategy. There is some evidence in literature that perceived deception can affect consumer loyalty intentions to service providers (Limbu et al., 2011; Román, 2010). According to Darke and Ritchie (2007), the feeling of being duped influences the present and the future behaviour of the consumer such as repeated purchase of loan products. Some loan customers may never want to come back to the service provider for same or another type of loan simply because they were previous deceived by the loan service provider in some manner. However, in spite of the apparent perceived deception, some deceived clients may still obtain loans in the future from the same financial service provider or another for other reasons such as the usefulness of the loans to the customer. Therefore, in the present study we hypothesize that:

H6: Consumer perceived deception will have significantly negative effect on client's intention to acquire future loans from a loan service provider.

\section{Methodology}

The population consisted of customers who have acquired loan facilities from various financial institutions in Ghana. A convenient sample size of 500 respondents was chosen for the study. In order to collect data of high quality that 
reflect customers' opinion and improve representativeness of the sample, a survey was conducted in the central business district of Kumasi in Ghana in August 2014. Out of the 500 questionnaire administered, a 371 usable questionnaire were obtained, representing $74.2 \%$ response rate.

A self-administered, structured questionnaire was developed and pre-tested to a sample of 10 customers. Adjustments were made based on the pre-test to get a more effective instrument. After that the questionnaire was finally administered to the customers through personal contact by researchers for nearly two weeks. We used informed consent form to seek permission from the respondents and assured them of anonymity and confidentiality of their responses.

A five- point Likert scale was used to measure variables for the research constructs as recommended in previous work (Danaher \& Haddrell, 1996; Delvin et al., 1993). The Likert scale ranged from strongly disagree to strongly agree, coded 1 to 5 respectively. In all, the measurement items for the seven multi-item constructs had 20 items that were derived from previous studies and modified to suit the research context as shown in Table 1. In this regard, CPD was a modelled as a second-order multi-dimensional construct consisting of two first-order multi-item constructs, namely, perceived veracity and perceived ethics. The other constructs in the model were trust, satisfaction, attitude towards loans, likelihood to recommend and future intention for loan, which were modelled primarily as consequence of CPD. The questionnaire also contained respondents' demographic data: gender, age, education, income and loan characteristics, among others.

Table 1. Constructs and measurement items

\begin{tabular}{|c|c|c|c|}
\hline Constructs & Code & Measurement items & Source \\
\hline \multirow{3}{*}{$\begin{array}{l}\text { Perceived } \\
\text { veracity }\end{array}$} & VER1 & This supplier is open in dealing with us & \multirow{4}{*}{$\begin{array}{l}\text { Chaouachi et al., (2012), } \\
\text { Román (2010) }\end{array}$} \\
\hline & VER2 & When making important decisions, the supplier is concerned about our welfare & \\
\hline & VER3 & $\begin{array}{l}\text { When we share our problems with the supplier, we know that they will } \\
\text { respond with understanding }\end{array}$ & \\
\hline \multirow{5}{*}{ Perceived ethics } & VER4 & $\begin{array}{l}\text { In the future, we can count on the supplier to consider how its decisions and } \\
\text { actions will affect us. }\end{array}$ & \\
\hline & ETH1 & $\begin{array}{l}\text { Staff of my financial institution send false impressions to consumers about the } \\
\text { actual loan facility policies. }\end{array}$ & \multirow{4}{*}{$\begin{array}{l}\text { Chaouachi et } \\
\text { Román (2010) }\end{array}$} \\
\hline & ETH2 & $\begin{array}{l}\text { My financial institution's loan facility policies are contrary to the principles of } \\
\text { fair trade. }\end{array}$ & \\
\hline & ETH3 & $\begin{array}{l}\text { Staff of my financial institution are usually dishonest about deductions for } \\
\text { loan facility to customers. }\end{array}$ & \\
\hline & ETH4 & $\begin{array}{l}\text { Generally, staff of my financial institution provide false information to } \\
\text { customers in their loan promotional activities. }\end{array}$ & \\
\hline \multirow{3}{*}{$\begin{array}{l}\text { Quality } \\
\text { Information }\end{array}$} & INF1 & $\begin{array}{l}\text { Staff of my financial institution informed me that I need to understand their } \\
\text { comprehensive policy on the loan facility. }\end{array}$ & \multirow{3}{*}{ Self-developed } \\
\hline & INF2 & The staff explained to me in detail all the loan policies on the bank. & \\
\hline & INF3 & $\begin{array}{l}\text { The staff explained to me all the costs, deductions and interest I need to pay on } \\
\text { the loan. }\end{array}$ & \\
\hline \multirow{3}{*}{ Trust } & TRU1 & This bank is a trustworthy bank when it comes to deducting loan charges. & \multirow{3}{*}{$\begin{array}{l}\text { Morgan \& Hunt (1994), } \\
\text { Romani (2006) }\end{array}$} \\
\hline & TRU2 & I have confidence in this bank to deliver professional services in loan facility & \\
\hline & TRU3 & This bank is reliable bank in terms of granting of loans to me & \\
\hline \multirow{2}{*}{$\begin{array}{l}\text { Likelihood } \\
\text { recommend }\end{array}$} & LR1 & I will say positive things about this bank's loan facility to other people, & \multirow{2}{*}{$\begin{array}{l}\text { Coulter \& Roggeveen, (2012), } \\
\text { Lim \& Chung (2011), Nimako } \\
\text { \& Mensah (2013) }\end{array}$} \\
\hline & LR2 & I will recommend this bank's loan facility to others. & \\
\hline \multirow{2}{*}{ Satisfaction } & SAT1 & I am satisfied with the bank's loan facility process. & \multirow{2}{*}{$\begin{array}{l}\text { Cronin \& Taylor, (1992); } \\
\text { Nimako (2012) }\end{array}$} \\
\hline & SAT2 & Overall I am happy about the loan repayment terms. & \\
\hline \multirow{3}{*}{$\begin{array}{l}\text { Attitude towards } \\
\text { loan }\end{array}$} & ATT1 & Taking loan from a financial institution is a wise decision & \multirow{3}{*}{$\begin{array}{l}\text { Ajzen (1991), Ajzen \& } \\
\text { Fishbein } \quad(2005), \quad \text { Nimako, } \\
\text { Ntim, \& Mensah 2014) }\end{array}$} \\
\hline & ATT2 & Taking loan from a financial institution is a good behaviour & \\
\hline & ATT3 & I have positive attitude towards taking loans from banks. & \\
\hline \multirow[t]{2}{*}{ Future intention } & FINT1 & I will go to the bank for loans in the near future. & \multirow{2}{*}{$\begin{array}{l}\text { Limbu et al. (2011) Román, } \\
\text { 2010), Ajzen \& Fishbein } \\
(2005)\end{array}$} \\
\hline & FINT2 & I am determined to go to the bank for other loan facilities & \\
\hline
\end{tabular}




\section{Data Analysis and Results}

Data were analysed using descriptive analysis and partial least squares structural equation modelling approaches available in SPSS 16.0 and SmartPLS 2.0 (Ringle, Wende, \& Will, 2005) respectively.

\subsection{Respondents' Profile}

For the characteristics of the respondents, in terms of gender, $36.9 \%$ of the respondents were males and $63.1 \%$ were females. $46.7 \%$ of the respondents were 35 years and below, $38.8 \%$ were between the ages of 36 and 45 while $14.5 \%$ were 46 years and above. In terms of education, about $11 \%$ of them had lower than Diploma/Higher Diploma levels of education, $59 \%$ had Diploma level education and about $28 \%$ had degree level education. About $22 \%$ of the respondents earned a monthly income below USD 250, 59\% of them earned monthly income between USD 250 and USD 500, about $16 \%$ of them earned between USD 500 and USD 1000 and about $18 \%$ of them earned above USD $1000.93 \%$ of the respondent had taken loans within the past five years while only $7 \%$ of them had taken loans longer than five years. About $18 \%$ of the loans taken by respondents had a repayment period of one year, $68 \%$ of the loans taken covered a period of two to four years to repay and about $10 \%$ of the loans elapsed between 5 to 8 years and only $4 \%$ of the loans taken by respondents covered periods above 8 years.

\subsection{Assessment of PLS-SEM Model}

The structural model was analysed using SmartPLS 2.0 (Ringle, et al., 2005) to perform Partial Least Squares Structural Equation Modelling (PLS-SEM) to test the hypothesized relationships among the constructs in the proposed model depicted (see Figure 1). PLS-SEM was deemed most appropriate because of the predictive focus of the study (Chin, 2010). Moreover, PLS-SEM was chosen because of its distribution-free assumption which was appropriate for our purpose. For sample size considerations in PLS-SEM, according to Hair, Ringle and Sarstedt (2011, p.144), as a common rule of thumb for appropriate sample size for testing reflective PLS-SEM models is the rule of ten, which suggests ten times the largest number of indicators for a latent construct in the structural model. In this study, the highest number of indicators directed a latent construct (either perceived veracity or perceived ethics) at a time was four. Hence four multiplied by ten gives 40 cases; thus, our sample 371 respondents could be described as adequate. The SmartPLS 2.0 software was set to 500 bootstrap samples for the estimation of significance of the t-values (Chin, 2010). Generally, the PLS-SEM analysis followed Hair et al.'s (2011, p.144) two-step approach; estimation of the measurement (outer) model before the structural (inner) model.

\subsection{Measurement Model Reliability and Validity}

Construct reliability measures the extent of internal consistency of measures used, and it is assessed through at item factor loadings with acceptable value of 0.50 and through Cronbach's alpha with the acceptable level of 0.7 (Hair et al., 2010; Hair et al., 2011, p.144). From Table 2, all of the constructs have item loadings higher than the recommended 0.50. Then in Table 3, all Cronbach alphas are above 0.70 , indicating that these multiple measures are highly reliable for the measurement of each construct. Construct validity assesses the degree to which a measurement represents and logically connects the observed phenomenon to the construct through the fundamental theory (Fornell \& Larcker, 1981). It is assessed through convergent validity and discriminant validity (Hair et al., 2011).

Convergent validity can be assessed through average variance extracted (AVEs) that should have minimum loading of 0.5, and composite reliability (CR) with acceptable minimum of 0.70 (Fornell \& Larcker, 1981; Hair et al., 2011). From Table 3, the AVEs are all above 0.50 indicating that items for each construct together explains adequately the constructs they represent, supporting the convergent validity of the derived measures. Moreover, the CR values for all constructs range from 0.799 to 0.994 exceeding the acceptable requirement of 0.70 confirming convergent validity of the measurement (outer) model.

Discriminant validity was considered adequate since the square root of the AVEs (in the diagonal) are greater than their respective inter-construct correlations as is in Table 3 (Fornell \& Larcker, 1981). Additional support for discriminant validity comes through inspection of the cross-loadings (Table 2), which indicates that the measurement items for each construct load higher on their respective constructs than they load on other constructs (Chin, 2010; Hair et al., 2011). These confirm that the measurement items explains adequately their respective constructs more than they do explain other constructs in the structural model. Given that construct reliability and validity conditions of the measurement model are acceptable, we proceed to assess the psychometric properties of the structural (inner) model.

\subsection{Results of Consumer Perceived Deception as a Second-Order Construct}

In this study, we conceptualised CPD as a reflective second-order factor described by the two first-order latent variables: perceived veracity and ethics. As indicated in Table 3 and Table 4, each of the first order constructs had high factor loading: veracity (0.920) and perceived ethics (0.925). Each of the loadings is significant at 0.001 . This implies that each of the first-order constructs is a significant underlying factor in the measurement of CPD. 
Table 2. Item loading and cross loadings

\begin{tabular}{lllllllll}
\hline & \multicolumn{1}{c}{ ATT } & \multicolumn{1}{c}{ INFO } & ETHICS & \multicolumn{2}{c}{ VER } & FINT & LR & SAT \\
\hline ATT1 & $\mathbf{0 . 9 8 8}$ & 0.131 & 0.099 & 0.060 & 0.227 & 0.202 & 0.261 & 0.267 \\
ATT2 & $\mathbf{0 . 9 8 8}$ & 0.150 & 0.087 & 0.042 & 0.225 & 0.236 & 0.271 & 0.296 \\
ATT3 & $\mathbf{0 . 9 9 6}$ & 0.141 & 0.103 & 0.054 & 0.226 & 0.225 & 0.259 & 0.280 \\
DINF1 & 0.029 & $\mathbf{0 . 5 5 9}$ & -0.080 & -0.017 & 0.126 & 0.215 & 0.186 & 0.200 \\
DINF2 & 0.144 & $\mathbf{0 . 7 8 1}$ & -0.104 & -0.116 & 0.079 & 0.286 & 0.190 & 0.254 \\
DINF3 & 0.121 & $\mathbf{0 . 9 0 1}$ & -0.169 & -0.196 & 0.114 & 0.308 & 0.235 & 0.330 \\
ETH1 & 0.073 & -0.102 & $\mathbf{0 . 8 2 3}$ & 0.662 & 0.109 & -0.129 & -0.164 & -0.156 \\
ETH2 & 0.078 & -0.071 & $\mathbf{0 . 7 0 8}$ & 0.463 & 0.030 & -0.081 & -0.124 & -0.065 \\
ETH3 & 0.114 & -0.176 & $\mathbf{0 . 8 2 6}$ & 0.558 & 0.017 & -0.189 & -0.133 & -0.185 \\
ETH4 & 0.037 & -0.166 & $\mathbf{0 . 7 5 0}$ & 0.479 & 0.011 & -0.206 & -0.147 & -0.134 \\
VER1 & 0.086 & -0.072 & 0.361 & $\mathbf{0 . 6 2 9}$ & -0.014 & -0.081 & -0.125 & -0.103 \\
VER2 & 0.052 & -0.223 & 0.536 & $\mathbf{0 . 7 8 4}$ & 0.036 & -0.122 & -0.152 & -0.113 \\
VER3 & 0.031 & -0.112 & 0.590 & $\mathbf{0 . 8 4 2}$ & 0.058 & -0.102 & -0.081 & -0.136 \\
VER4 & 0.010 & -0.132 & 0.633 & $\mathbf{0 . 8 0 7}$ & 0.036 & -0.155 & -0.168 & -0.171 \\
FINT1 & 0.252 & 0.120 & 0.019 & 0.018 & $\mathbf{0 . 6 3 8}$ & 0.390 & 0.430 & 0.356 \\
FINT2 & 0.185 & 0.111 & 0.061 & 0.043 & $\mathbf{0 . 9 6 6}$ & 0.269 & 0.330 & 0.300 \\
LR1 & 0.238 & 0.312 & -0.183 & -0.109 & 0.310 & $\mathbf{0 . 9 0 1}$ & 0.531 & 0.619 \\
LR2 & 0.173 & 0.334 & -0.175 & -0.164 & 0.310 & $\mathbf{0 . 9 2 7}$ & 0.572 & 0.642 \\
SAT1 & 0.250 & 0.226 & -0.133 & -0.130 & 0.397 & 0.526 & $\mathbf{0 . 8 5 2}$ & 0.547 \\
SAT2 & 0.227 & 0.240 & -0.186 & -0.167 & 0.329 & 0.548 & $\mathbf{0 . 9 2 1}$ & 0.600 \\
TRU1 & 0.226 & 0.296 & -0.191 & -0.199 & 0.313 & 0.562 & 0.583 & $\mathbf{0 . 9 1 2}$ \\
TRU2 & 0.272 & 0.319 & -0.139 & -0.099 & 0.336 & 0.594 & 0.560 & $\mathbf{0 . 8 5 4}$ \\
TRU3 & 0.250 & 0.307 & -0.100 & -0.113 & 0.268 & 0.669 & 0.524 & $\mathbf{0 . 7 9 9}$ \\
\hline & & & & & & & &
\end{tabular}

Table 3. Construct Reliability and discriminant validity

\begin{tabular}{|c|c|c|c|c|c|c|c|c|c|c|c|}
\hline & ATT & ETHICS & FINT & INFO & LR & SAT & TRU & VER & AVE & $\mathrm{CR}$ & $\mathrm{CA}$ \\
\hline ATT & 0.990 & & & & & & & & 0.981 & 0.994 & 0.990 \\
\hline ETHICS & 0.098 & 0.779 & & & & & & & 0.606 & 0.860 & 0.782 \\
\hline FINT & 0.228 & 0.057 & 0.818 & & & & & & 0.670 & 0.796 & 0.588 \\
\hline INFO & 0.142 & -0.166 & 0.128 & 0.760 & & & & & 0.578 & 0.799 & 0.673 \\
\hline LR & 0.222 & -0.195 & 0.339 & 0.354 & 0.914 & & & & 0.836 & 0.911 & 0.805 \\
\hline SAT & 0.266 & -0.183 & 0.402 & 0.263 & 0.604 & 0.887 & & & 0.787 & 0.881 & 0.735 \\
\hline TRU & 0.283 & -0.177 & 0.356 & 0.352 & 0.690 & 0.648 & 0.856 & & 0.733 & 0.892 & 0.826 \\
\hline VER & 0.053 & 0.701 & 0.042 & -0.178 & -0.151 & -0.169 & -0.172 & 0.770 & 0.593 & 0.852 & 0.768 \\
\hline
\end{tabular}

Notes: square roots of AVEs are in the diagonal; correlations are below the diagonal; AVE-Average variance extracted, CR- Composite reliability, CA - Cronbach's alp

Table 4. Test of customer perceived deception as a second-order construct

\begin{tabular}{clllll}
\hline Relationship & Regression weight & Standard Error & T-Statistics & p-value & Remarks \\
\hline CPD -> Ethics & 0.925 & 0.008 & 114.976 & $0.000^{* * *}$ & Significant \\
CPD -> Veracity & 0.920 & 0.009 & 93.265 & $0.000^{* * *}$ & Significant \\
\hline
\end{tabular}

Notes: *** significant at 0.001

\subsection{Results of Structural Model}

In PLS-SEM, structural models' validity are assessed through the strength of regression weights, t-values, p-values for significance of t-statistics, as well as effect sizes of independent variables on the dependent variables (Chin, 2010; Hair et al., 2011). The results of hypothesis testing are presented in Table 5 
Table 5. Results of hypothesis testing

\begin{tabular}{lllllll}
\hline & $\begin{array}{l}\text { Hypothesized } \\
\text { relationship }\end{array}$ & Regression weight & Standard Error & T-Statistics & p-value & Remarks on hypothesis \\
\hline H1 & INF->CPD & -01869 & 0.05 & 3.739 & $0.000^{* * *}$ & Supported \\
H2 & CPD -> TRU & -0.189 & 0.053 & 3.533 & $0.000^{* * *}$ & Supported \\
H3 & CPD -> ATT & 0.082 & 0.052 & 1.583 & 0.114 & Supported \\
H4 & CPD -> SAT & -0.192 & 0.055 & 3.477 & $0.001^{* *}$ & Supported \\
H5 & CPD -> LR & -0.188 & 0.055 & 3.431 & $0.001^{* *}$ & Supported \\
H6 & CPD -> FINT & 0.053 & 0.078 & 0.680 & 0.496 & Not supported \\
\hline
\end{tabular}

Note: $* *$ significant at $0.01, * * *$ significant at 0.001

The results in Table 5 show that, five out of six hypotheses were supported by the data. First of all, for the only antecedent of CPD, loan information quality significantly reduces CPD, confirming hypothesis $\mathrm{H} 1$. For the consequence of $\mathrm{CPD}, \mathrm{CPD}$ has significantly negative effect on Trust $(\beta=-0.189, \mathrm{t}=3.5, \mathrm{p}<0.001)$, providing support for hypothesis H2. CPD did not significantly influence general attitude towards loans $(\beta=0.082, \mathrm{t}=1.583$, $\mathrm{p}>0.05$ ), confirming hypothesis H3. Moreover, CPD has significantly negative effect on satisfaction for loan service $(\beta=-0.192, \mathrm{t}=3.477, \mathrm{p}<0.05)$, providing support for hypothesis H4. CPD negatively influenced likelihood to recommend the loan to others $(\beta=-0.188, \mathrm{t}=3.431, \mathrm{p}<0.05)$, confirming hypothesis H5. Finally, CPD did not significantly influenced future intentions for the loan service $(\beta=0.053, \mathrm{t}=0.680, \mathrm{p}>0.05)$ confirming hypothesis H6. Among the dependent (effect) variables, the results indicate that CPD had the greatest influence on satisfaction $(19.2 \%)$, followed by trust $(18.9 \%)$ and likelihood to recommend $(18.8 \%)$.

\subsection{Predictive Power Analysis}

The R-Square measures the predictive power of the structural model in PLS analysis. In this study, since there was only one multi-dimensional independent construct, the predictive power of the independent variable to their respective dependent variables was assessed by the size of the R-square for each of the effects of CPD. The effect size of each of CPD on trust, satisfaction and likelihood to recommend is presented in Table 6. Cohen (1988) provides the following guidelines for interpreting effect sizes: Less than $0.02-$ no effect, Small - 0.02, medium 0.15 , large -0.35 .

Table 6. Predictive power analysis

\begin{tabular}{lll}
\hline Dependent variables & $\mathbf{R}^{2}$ included & Remarks \\
\hline INF -> CPD & 0.035 & Small effect \\
CPD -> TRU & 0.036 & Small effect \\
CPD -> SAT & 0.037 & Small effect \\
CPD -> LR & 0.036 & Small effect \\
\hline
\end{tabular}

Notes: Effect size: 0 - none, 0.02 - small, 0.15 - medium, 0.35 - large (Cohen, 1988)

From Table 6, the model as a whole predicts about 4\% trust, likelihood to recommend and satisfaction respectively, indicating a small effect size. Despite the apparent small effect size of the independent variable to the dependent variables, the proposed model is significant and provides avenues for future empirical research in CPD, which is relatively under-researched area in the context of financial services.

\section{Discussion and Implications}

In this research, the overarching purpose was to assess the antecedent and consequence of CPD in financial service context from a developing country perspective. Using data from the a survey of 371 loan customers of leading financial service providers in Ghana, the results show that CPD has a negative effect on trust, satisfaction and likelihood to recommend loan service providers. However, CPD did not influence respondents' attitude towards loans and future intentions for loan acquisition.

First, the results have revealed that CPD can be significantly reduced when loan policy information is effectively communicated and explained to loan customers. This confirms that failure to deliver quality information about loans to customer could result in high CPD and that information quality is a vital aspect of financial service delivery (De Mel, McKenzie, \& Woodruff, 2011; Owusu-Frimpong, 2008; Xia, 2014). It is the responsibility of loan service providers to disclose all relevant and material information about loans to clients. This helps to reduce uncertainty and misinformation that customers are likely to experience if left to read loan policies themselves. The findings imply that while CPD might be inevitable, firms should provide for effective delivery of quality information about loan policy to clients. In this regard, staff should take time to explain in detail the terms and condition of the loan policy before and during the loan acquisition and payment process in order to minimize CPD. 
Second, our finding on the relationship between perceived deception and trust is consistent with the findings of previous studies (e.g. Román, 2010; Romani, 2006). Deceived customers are less likely to hold loan service providers in trust. They therefore lose confidence in the loan service provider and its loan products. In the relationship marketing paradigm, consumer trust is central to sustaining profitability of the firm thorough customer lifetime value (Morgan \& Hunt 1994; Hennig-Thurau, Gwinner, \& Gremler, 2002; Kim, \& Qu, 2012). The finding on trust in the present study has revealed that, in the area of loan service delivery, client trust in the service provider can be negatively affected by client perception of deception in the loan acquisition and repayment process. Thus, taking advantage of the vulnerability of the consumer regarding the terms and conditions in the delivery of loan service to customers can be detrimental to client trust reposed in loan service providers.

Third, even though previous research has argued that CPD can negatively influence client's attitude towards specific advertising programmes (Chaouachi et al., 2012; Newell et al., 1996), our findings indicate that CPD might not have significantly negative effect on customer's attitude towards loan service offerings in general. Our findings suggest that, at best clients might developed negative attitude towards the acquisition of a particular loan facility from a particular service provider, but might still possess a positive attitude towards loan acquisition in general, given that the clients have value and perceived usefulness for the loans acquired for This implies that deceived consumers might still have positive attitude the acquisition of loans for their personal and business needs. This finding implies that scholars and financial managers should be able to understand not only client attitude towards specific financial services but also their general attitude in order to be able to deduce these attitudinal differences in consumer behaviour towards loan services for management strategy.

Fourth, our findings suggest that CPD negatively affects the client satisfaction for loan service delivery, confirming existing CPD literature (Chaouachi et al., 2012; Román, 2010). Deception introduces a feeling of disappointment and a sense of displeasure in loan customers. In the end, clients become overall dissatisfied with the loan service delivery. Client dissatisfaction can in turn influence client to switch to other loan service providers (Keaveney, 1995; Nimako 2012; Panther, \& Farquhar, 2004) or engage in negative word-of-mouth communication about the current financial service provider (Nimako \& Mensah, 2012).

Fifth, the finding on the relationship between CDP and client's likelihood to recommend loan service provider is consistent with the general financial marketing literature (e.g., Coulter \& Roggeveen, 2012; Lang, 2011; Lim \& Chung, 2011; Sweeney, Soutar, \& Mazzarol, 2012). In particular, this study has provided empirical evidence that CPD has negative influence on client recommendation of loan service provider. Therefore, loan customers are likely to speak evil of and discourage other clients and potential clients from acquiring loan facility from a financial service provider, confirming several studies (e.g., Coulter \& Roggeveen, 2012; Lim \& Chung, 2011; Sweeney, Soutar, \& Mazzarol, 2012). Negative recommendation could be detrimental to the survival and sustainability of a financial firm offering loan services in that it reflect negative image of a service provider, which in turn can influence potential clients' decision to become customers.

Finally, the results revealed that CPD did not have significantly negative effect on clients' intention for future loans. Although, existing literature postulates that perceived deception can negatively affect the present and the future behaviour of consumers, as well as their consumer loyalty intentions to service providers (Darke \& Ritchie, 2007; Limbu et al., 2010), the present study indicates that the relationship between CPD and future intentions for loans might not be a straight-forward one.

Thus, CPD might not automatically have negative influence consumer intentions for future loans for several reasons. To begin with, in the case where a consumer perceives that there are no comparable and better alternatives to the loan service delivered by a financial institution, in spite of the CPD, consumers are still likely to go for loans from the unscrupulous service provider. Another reason is that, where the consumer perceives that cost of the level of deception to be comparatively less than the value and perceived usefulness of the loan service received, the consumer's future intentions for the same or similar loans from the financial service provider might not be negatively affected. Moreover, it is possible that if the consumer feels deceived and is still satisfied with the many aspects of the whole loans acquisition and repayment process such as customer service and loan repayment terms, he/she will be more likely to come back to the financial service provider for future loans. Furthermore, if loan service provider is able to manage effectively any customer complaints and reports about CPD with loan services it could also neutralize any negative effect of CPD on clients' future intentions for loan acquisition.

\subsection{Theoretical Contribution}

The present study is one of initial studies that extends our theoretical understanding of the antecedents and consequence of CPD in terms of context and variables included. First, this paper has validated an important antecedent to CPD, which is loan policy information quality. It, therefore, contributes to filling the void in the extant literature regarding the antecedents of CPD. Second, this paper contributes to filling the void in the extant literature regarding evidence of the direct effect of CPD on consumer behaviour such as trust, satisfaction and behavioural 
intentions for service providers, especially in financial service context. While existing literature has focused on testing the influence of CPD on only one or two factors at a time such as sales volume, evaluation of product attributes (Estrada, 2006; Newell, Goldsmith, \& Banzhaf, 1998), attitude towards advertising (Chaouachi, et al., 2012), loyalty (Limbu t al., 2011; Román, 2010), the present study has examined the simultaneous effect of CPD trust, satisfaction, recommendation, future intentions and attitude towards loans, which are critically important in developing and sustaining customer relationship in financial services context. Thus, this study has furthered our theoretical understanding that CPD has a negative effect on trust, satisfaction and likelihood to recommend loan service providers, but might not negatively influence on respondents' attitude towards loans in general nor on their future intentions for loan acquisition in particular.

Third, this study has provided some empirical evidence that while CPD may negatively influence consumer attitude towards a particular service provider or a specific loan facility, it may not necessarily influence consumer attitude towards loans in general and customers' intention for future loans for several reasons. It, therefore, implies that more theoretical and empirical evidence are required to explain the key factors that are likely to moderate the relationship between CPD and some of its consequence such as attitude towards loans in general and future intentions for loans.

Fourth, this study is one of the few studies that have extended our understanding of CPD to the context of financial services in developing countries in general and loan service in particular, which is under-researched area. In particular, it has attempted to contextualize the conceptualization of CPD phenomenon and its consequence, operationalized its measurement items, and applied the CPD framework to the financial services context.

\subsection{Managerial Contribution}

Managerially, the findings of this study imply that financial service providers should focus on reducing CPD since it can have seriously adverse consequence on consumer trust, satisfaction and recommendation of service provider. Therefore, financial managers should endeavor to maintain truthfulness to all areas in loan policies (terms and conditions) as promised and ensure that staff exhibit high level of professionalism and ethical behaviour in dealing with clients in loan acquisition and repayment process.

The non-significant effects of CPD on general attitude towards loans and future intentions for loans imply that in spite of the general perception that consumer might have regarding the presence of perceived deception in loan service delivery in general, consumers might still have positive attitude towards loans and would still patronize loan services for their personal and business purposes. Therefore, financial managers in loan service firms must develop strategies to attract clients by highlighting the perceived value and usefulness of specific loan facilities being delivered by a firm to customers and ensure that these value propositions are really experienced by customers.

In addition, management should provide effective customer complaint strategies to handle any complaints and reports of CPD in the public media or those reported by customers in order to ensure that customers and the general public do not lose trust in the credibility of the loan service provider (Nimako \& Mensah, 2012). In this regard, loans service providers should endeavor to explain, correct, render unqualified apology and compensate customers who suffer from any CPD of the part of the loan service provider (Nimako \& Mensah, 2012).

\section{Limitations and Future Research}

While this study makes important contributions to theory and management of loan services in financial markets, it is limited in context and variables captured. The use of only participants in Ghana, a developing country context, limits the generalizability of the findings. Future research should extend the proposed model to similar service contexts in other countries. Moreover, in this study, we did not examine the role of moderating variables that can explain the non-significant relationship between CPD and general attitude towards loans and future intentions for loans. Such moderating variables may include perceived value and usefulness of loans, availability of better alternatives, level of satisfaction, flexibility of loan terms and conditions, among other things. It is recommended that future research should attempt to explore these areas in addition to the antecedents of CPD in order to enhance our full understanding of the antecedents and consequence of CPD in different countries and research contexts.

\section{Conclusion}

This study assesses the antecedent and consequence of CPD on consumer trust, satisfaction, attitude recommendation and intentions to acquire future loans from financial service providers. It draws on existing literature in consumer deception and relationship marketing constructs in financial market to develop a conceptual framework of consequence of $\mathrm{CPD}$ in a developing country financial market.

Using data from a survey of 371 loan customers of leading financial service providers in Ghana, the results show that CPD has negative effects on trust, satisfaction and likelihood to recommend loan service providers. However, CPD did not influence respondents' attitude towards loans and future intentions for loan acquisition. The unique contributions of this study to the CPD and financial marketing literature are two-fold. First, it extends our understanding of CPD in a new and under-researched context of loan financial market in developing countries. 
Second, this study provides empirical evidence on five key consequence of CPD. Contrary to conventional business wisdom, our findings suggest CPD might not necessarily affect consumers general attitude towards loans and their intentions to acquire future loans due to perceived value and usefulness of loans, level of satisfaction, lack of availability a better substitutes and highly favourable terms and conditions of the loan. While this study is limited in terms of generalizability of the findings in developing countries, it provides avenues for further research to test the applicability of the proposed research model in financial markets in other research settings.

\section{References}

Aditya, R. N. (2001). The Psychology of Deception in Marketing: A Conceptual Framework for Research and Practice. Psychology \& Marketing, 18(7), 735.

Ajzen, I. (1991). The theory of planned behavior. Organizational Behavior and Human Decision Processes, 50, $179-211$

Ajzen, I., \& Fishbein, M. (2005). The Influence of Attitudes on Behavior. In The Handbook of Attitudes, D. Albarracín, B. T. Johnson, and M. P. Zanna (Eds.), Mahwah, NJ: Erlbaum (pp. 173-221).

Armstrong Gary, M., \& Mclennan, James, P. (1973). The Federal Trade Commission and the Investigation and Regulation of Deception in Advertising. InThomas U. Greer (Ed.), Increasing Marketing Productivity/Conceptual and Methodological Foundations of Marketing (pp. 430-434). Chicago: American Marketing Association.

Barroso, C., \& Picón, A. (2012). Multi-dimensional analysis of perceived switching costs. Industrial Marketing Management, 41(3), 531-543. http://dx.doi.org/10.1016/j.indmarman.2011.06.020

Belanche, D., Casaló, L. V., \& Guinalíu M. (2013). The Role of Consumer Happiness in Relationship Marketing. Journal of Relationship Marketing, 12(2), 79-94. http://dx.doi.org/10.1080/15332667.2013.794099

Bolton, R. N. (2011). Comment: Customer Engagement. Journal of Service Research, 14(3), 272-274.

Boush, D. M., Friestad, M., \& Wright, P. (2009). Deception in the Marketplace: The Psychology of Deceptive Persuasion and Consumer Self-Protection. Routledge, 264.

Buller, D. B., \& Burgoon, J. K. (1996). Interpersonal Deception Theory. Communication Theory, 6(3), 203-242.

Chaouachi, S. G., Rached, K. S. B., \& Saied, K. (2012). Perceived Deception in Advertising: Proposition of a Measurement Scale. Journal of Marketing Research \& Case Studies, 1-14.

Chin, W. W. (2010). How to write up and report PLS analyses. In V. E. Vinzi, W. W. Chin, J. Henseler, \& H. Wang (Eds.), Handbook of partial least squares: Concepts, methods and applications in marketing and related fields (pp. 655-690). Berlin: Springer.

Coulter, K. S., \& Roggeveen, A. (2012). "Like it or not": Consumer responses to word-of-mouth communication in on-line social networks. Management Research Review, 35(9), 878-899.

Danaher, P. J., \& Haddrell, V. (1996). A comparison of question scales used for measuring customer satisfaction. International Journal of Service Industry Management, 7(4), 4-26.

Ekman, P. (1992). Telling Lies, Clues to Deceit in the Marketplace, Politics and Marriage (2nd ed.). New York: W. W. Norton \& Company.

Estrada, M. L. (2006). The Impact of Deceptive Advertising on Corporate Sales. Honors Thesis, California University, Long Beach, CA.

Ford, C. V. (1996). Lies !Lies!!Lies!!!The Psychology of Deceit. Washington, DC: American Psychiatric Press.

Fornell, C., \& Larcker, D. F. (1981). Evaluating structural equation models with unobservable variables and measurement error. Journal of Marketing Research, 18, 39-50.

FTC. (1983). FTC Policy Statement on Deception. Retrieved April 26, 2012, from http://ftc.gov/bcp/policystmt/addecept.htm/

Gao, Zhihong (2008). Controlling Deceptive Advertising in China: An Overview. Journal of Public Policy \& Marketing, 27(2), 165-177.

Grazioli, S., \& Jarvenpa, S. L. (2003). Consumer and Business Deception over the Internet: Content Analysis of Documentary Evidence. International Journal of Electronic Commerce, 7, 93-118.

Hair, J. F., Ringle, C. M., \& Sarstedt, M. (2011). PLS-SEM: Indeed a Silver Bullet. Journal of Marketing Theory and Practice, 19(2), 139-151.

Hastak Manoj, \& Mazis Michael, B. (2011). Deception by Implication: A Typology of Truthful but Misleading Advertising and Labelling Claims. Journal of Public Policy \& Marketing.

Hennig-Thurau, T., Gwinner, K. P., \& Gremler, D. D. (2002). Understanding relationshipmarketing outcomes an 
integration of relational benefits and relationship quality. Journal of service research, 4(3), 230-247.

Hyman, M. R., Tansey, R., \& Clark, J. W. (1994). Research on Advertising Ethics: Past, Present and Future. Journal of Advertising, 23(3), 5.

Jaakkola, E., \& Alexander, M. (2014). The Role of Customer Engagement Behavior in Value Co-Creation A Service System Perspective. Journal of Service Research, 1-15.

Keaveney, S. M. (1995). Customer switching behavior in service industries: An exploratory study. Journal of Marketing, 50(2), 71-82.

Kim, M., \& Qu, H. (2012). A refined model of relationship selling between meeting planners and suppliers. Journal of Travel \& Tourism Marketing, 29(2), 105-118.

Kotler, P., \& Keller, K.L. (2012). Marketing Management (14th ed.). Upper Saddle River, NJ: Prentice Hall.

Lang, B. (2011). How word of mouth communication varies across service encounters. Managing ServiceQuality, 21(6), 583-598.

Lim, B. C., \& Chung, C. M. (2011). The impact of word-of-mouth communication on attribute evaluation. Journal of Business Research, 64(1), 18-23.

Limbu, Y. B., Wolf, M., \& Lunsford, D. L. (2011). Consumers' perceptions of online ethics and its effects on satisfaction and loyalty. Journal of Research in Interactive Marketing, 5(1), 71-89.

Lord, K. R., \& Kim, C. K. (1995). Inoculating Consumers against Deception: the Influence of Framing and Evectional Style. Journal of Consumer Policy, 18, 123.

Masip Jaune, Garrido Eugenio, \& Herrero Carmen. (2004). Defining Deception. Anales De Psicologia, 20(1), 147-171.

Newell, S. J., Goldsmith, R. E., \& Banzhaf, E. J. (1998). The Effect of Misleading Environmental Claims on Consumer Perceptions of Advertisements. Journal of Marketing Theory and Practice, 6(2), 48.

Ng, S., David, M. E., \& Dagger, T. S. (2011). Generating positive word-of-mouth in the service experience. Managing Service Quality, 21(2), 133-151.

Nimako, S. G., \& Mensah, A. F. (2012). Motivation for Customer Complaining and Non Complaining Behaviour Towards Mobile Telecommunication Services. Asian Journal of Business Management, 4(3), 310-320.

Nimako, S. G., \& Mensah, A. F. (2013). Examining the Relationships among Antecedents of Guests' Behavioural Intentions in Ghana's Hospitality Industry: A Structural Equation Modelling Approach. Asian Journal of Business and Management, 5(2) 252-266.

Nimako, S.G. (2012). Linking quality, satisfaction and behaviour intentions in Ghana's mobile telecommunication industry. Eur. J. Bus. Manag., 4(7), 1-17.

Nimako, S.G., Ntim, B. A., \& Mensah, A. F. (2014). Effects of Mobile Number Portability Adoption on Consumer switching intentions. International Journal of Marketing Studies, 6(2), 117-134. http://dx.doi.org/10.5539/ijms.v6n2p117

Panther, T., \& Farquhar, J. (2004). Customer responses to dissatisfaction with financial service providers: an exploration of why some stay while others switch. Journal of Financial Services Marketing, 8(4), 343-353.

Reichheld, F. (1996). Loyalty Effect: The Hidden Force Behind Growth, Profits and Lasting Value. The Harvard Business School Press, Cambridge, MA.

Ringle, C.M., Wende, S., \& Will, S. (2005). SmartPLS 2.0 (M3) Beta. Hamburg, Retrieved from http://www.smartpls.de

Román, S. (2007). The Ethics of Online Retailing: A Scale Development and Validation from the Consumers' Perspective. Journal of Business Ethics, 72, 131-148.

Román, S. (2010). Relational consequences of perceived deception in online shopping: the moderating roles of type of product, consumer's attitude toward the internet and consumer's demographics. Journal of Business Ethics, 95(3), 373-391.

Sweeney, J. C., Soutar, G. N., \& Mazzarol, T. (2012). Word of mouth: measuring the power of individual messages. European Journal of Marketing, 46(1/2), 237-257.

Xiao, B., \& Tan, C. (2006). Reducing the Perceived Deception of Product Recommendation Agent: The Impact of Perceived Verifiability and Perceived Similarity, Proceedings of the Fifth Annual Workshop on HCI Research in MIS, Milwaukee, WI, December 9, 2006.

Zeithaml, V.A. (2000). Service quality, profitability and the economic worth of customers: what we know and what we need to learn. Journal of the Academy of Marketing Science, 28(1), 67-85. 